\title{
Gone but not forgotten
}

\author{
D. Henderson* \\ Department of Chemistry and Biochemistry, Brigham Young University, Provo UT 84602-5700
}

Received June 16, 2014

\begin{abstract}
In this reminiscence I discuss the influence of Henry Eyring and John Barker upon my life and work. Others, especially my family, have been of even greater personal influence. However, these two great and grand men were of tremendous scientific influence. Of course, others who came before Eyring and Barker, especially Boltzmann and van der Waals and later Onsager and Eyring's contemporary, Kirkwood, have been influential, but only indirectly as I never met them. Eyring and Barker are not the only scientists who have inspired me. Many who influenced me have contributed articles to this special issue or have worked with me. I single out Eyring and Barker because I met them early in my career and because they have passed away and are now present only in spirit. They are gone but should not be forgotten; I take this occasion to remind the readers about these two outstanding scientists and fine men and offer this reminiscence as thanks to them.
\end{abstract}

Key words: chemical kinetics, theory of liquids, perturbation theory

PACS: $01.60 .+q, 01.65 .+g, 64.10 .+h, 82.20 .-w, 82.20 . K h$

Isaac Newton, in one of his few modest moments, said that the reason that he could see so far is because he stood on the shoulders of those who preceeded him. This is true of us all. Boltzmann and van der Waals have provided me with great insight. More recently, Onsager and Kirkwood, provided foundations upon which I have built. However, I know those gentlemen only through their work. I knew and worked with both Eyring and Barker and admired them greatly. Of course, I have worked with and admired many others. Many have contributed to this issue. Henry Eyring and John Barker were important scientists in my career and good friends but have passed away and cannot participate in this volume. They have gone but are not forgotten.

\section{Henry Eyring (1901-81)}

Henry Eyring appears in figure 1. This is a painting that hangs in foyer of the Universiy of Utah chemistry building.

I first became aware of Henry Eyring when I was quite young. My mother told me excitedly that she had learned in a church class that one could prove the existence of God by science. Prove is really too strong a word. My mother misunderstood. Rather the author of the lesson used the example of a power series to demonstrate that by one could approach God in successive, hopefully convergent, steps. Later, when talking with Henry Eyring, I learned that he was the author of this lesson.

My first real contact with Henry was as an undergraduate at the University of British Columbia, when Frank Peters, a friend who was majoring in metallurgy, drew my attention to the fact that Henry Eyring, a member of my church, was to be a seminar speaker at the university. Frank was impressed by Henry's breadth of knowledge, his lucid presentation of his ideas, and his friendly manner. It was no coincidence that a few years later I found myself to be Eyring's research student at the University of Utah.

Eyring was not born into a scientific family. He was born in Colonia Juarez, a small town in northern Mexico. Colonia Juarez may be found by looking at a map of northern Mexico and following the railway line southwest from El Paso for around 200 kilometers to Nuevos Casas Grandes and then going west on

\footnotetext{
*E-mail: doug@chem.byu.edu
} 


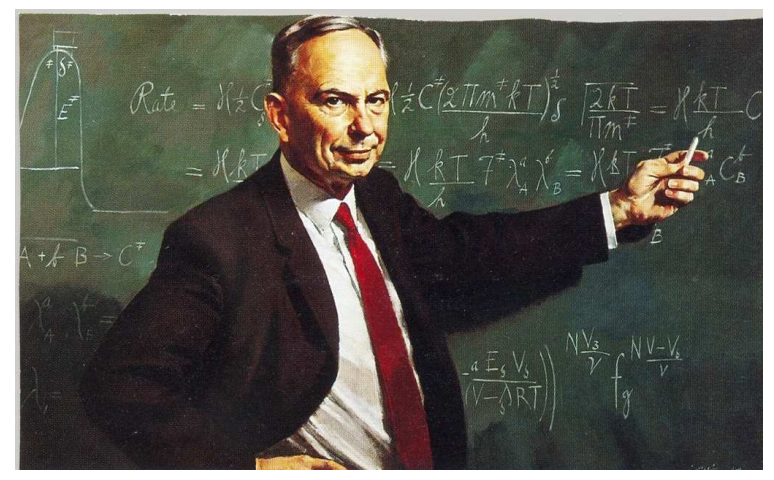

Figure 1. Henry Eyring.

a secondary road for about 20 kilometers. Colonia Juarez is at the end of this road. The major industry of the region is the growing of fruit. However, Henry's father was a rancher with a large herd of cattle. The railroad was very valuable for the export of produce from the region.

At the time of Henry's birth, and to a somewhat lesser extent today, Colonia Juarez was populated mostly by Americans and decendents of Americans. The word "Colonia" gives the impression to English speakers of a colony of people who came to exploit the locals, get rich and then retire to their homeland. People in Utah tend to refer to Colonia Juarez and similar towns as the "Mexican colonies". However, in Mexico, the word colonia has the connotation of a neighborhood. For example, the neighborhood of Mexico City in which Rose-Marie and I lived for a few years is Colonia del Valle. The residents of Colonia Juarez came to stay. Henry's father became a Mexican citizen. Henry was a Mexican citizen until he became a naturalized US citizen in the mid 1930's. The Mexican revolution changed things and, for safety, the Eyring family departed hurriedly on the railroad with their friends and neighbors and went to El Paso. Many of his relatives returned to Mexico when the situation stabilized but after some soul searching Henry's family went to Arizona, where they cleared their land, farmed and lived in reduced circumstances. It is worth noting that Henry contributed to the payment of the mortgage on the farm for a number of years after he left home.

Henry went first to the University of Arizona in Tucson and then to the University of California in Berkeley, where he obtained his PhD in chemistry. A few years after graduation, he married Mildred Bennion; they went to Germany, where he was a post-doctoral fellow at the Kaiser Wilhelm Institute (now the Max Planck Institute) in Dahlem, a suburb of Berlin. While there, he and Polanyi [1] made the first quantum mechanical calculation of the energy surface for a chemical reaction. On his return to the US, he spent a short stay at Berkeley, where his first son was born, and then settled in as a faculty member at Princeton, where he ultimately became a professor of chemistry. While at Princeton his family grew with the addition of two more sons. At Princeton, he developed [2] what he called absolute reaction rate theory, with which his name is forever associated. Either the Eyring-Polanyi energy surface calculation or his rate theory was worthy of a Nobel Prize but one never came. Some of Henry's associates were shocked (their word) by this oversight. Henry accepted this in good grace.

By the time that I met Henry, he had moved to the University of Utah, where he became the founding Dean of the Graduate School of the university. Although he was a dean, he still taught classes in his office and had PhD students. I met Henry when he wore all these multiple hats. While at Princeton, Henry became interested in developing a theory of the liquid state. This interest was due to the fact that his reaction rate theory required the partition functions of the reactants. His classic rate theory paper considered low density gases and needed only the partition function of an ideal gas. However, many important reactions occur in liquids and for this the partition function of a liquid is needed. At Princeton he developed a cell model of a liquid. When applied to a low density fluid, this model lacks a factor, $\exp (N)$, that appears in the entropy of an ideal gas. This factor should appear in a natural way but Eyring reasoned that inserting the factor, even arbitrarily, was preferable to not having it at all. He called this rather arbitrary term the communal entropy because it was a measure of the multiple occupancy of the 
cells and was shared by all the molecules.

Subsequently, Eyring thought that a lattice model should have empty sites or cells with holes. He reasoned that, when a liquid molecule evaporated, it left an empty cell behind. He regarded these holes as approximate mirror images of the vapor molecules. The entropy of mixing of the molecules and holes provided the communal entropy. If the liquid consisted of molecules and holes that exactly mirrored the vapor molecules, the sum of the densities of the coexisting liquid and vapor phases should be a constant. This provided a simple qualitative explanation of the law of rectilinear diameters, where the observed sum of the densities of the coexisting vapor and liquid is not a constant but is a linear function of the temperature. Extending this idea, Eyring suggested that the partition function, $Z$, of a liquid could be written as

$$
Z=Z_{\mathrm{s}}^{\frac{V_{\mathrm{s}}}{V}} Z_{\mathrm{g}}^{\frac{V-V_{\mathrm{s}}}{V}}
$$

where $Z_{\mathrm{s}}, Z_{\mathrm{g}}, V_{\mathrm{s}}$ and $V$ are, respectively, the partition functions of the solid and ideal gas phases, and the molar volumes of solid and liquid phases. For $Z_{\mathrm{s}}$ and $Z_{\mathrm{g}}$, the partition functions of the Einstein model of a solid and the ideal gas were used. Empirical parameters were used in $Z_{\mathrm{s}}$ and for $V_{\mathrm{s}}$.

Equation (1) suggests that the heat capacity, $C$, of liquid argon should be

$$
\frac{C}{N k}=3 \frac{V_{\mathrm{s}}}{V}+\frac{3}{2} \frac{V-V_{\mathrm{s}}}{V},
$$

where $N$ is the number of molecules in the liquid, $k$ is Boltzmann's constant, and $T$ is the temperature of the liquid. This result is remarkedly accurate. It does fail to predict the singularity of the heat capacity at the critical point. Eyring's critics made too much of this 'failing' since their theories also shared this failing. Eyring called this procedure the significant structure theory of the liquid state [3]. The name was chosen because Eyring thought that the molecules and holes were the significant structural elements of a liquid. I was put to work applying these ideas and presented the result for a thesis. The prospect interested me because at the time the lack of a theory of the liquid state was regarded as one of the major stumbling blocks in science. For me, significant structure theory did not remove this stumbling block. The removal of the stumbling block came when I worked with Barker a few years later and when he and I had spectacular (John Rowlinson's term) success.

Significant structure theory is not a true theory; it is a description. It provides no insight into the relation of the thermodynamic properties of a liquid to the intermolecular interactions between the liquid molecules. It is an interpolation formula to pass between the solid and gas phases. The critics of significant structure theory were too harsh because it does focus on the essential importance of the volume or density and assigns a lesser role to the temperature in determining the properties of a liquid. This became clear as a result of the work of Barker and me. At the time of my graduate work, the reverse was thought to be the case. Also, it is worth noting that equation (1) implies that the portion of the free energy of a liquid that results from those molecules that have not evaporated contains a term that is proportional to $V_{\mathrm{s}} / V$, or to the density, of the liquid. This is similar to the ideas of van der Waals. I will return to this point shortly.

After graduation, I tried to develop a more rigorous theory of the liquid state that involved holes or vacant cells. I had mixed success in this endevour but I did publish a paper that captured the interest of John Barker. Despite my apostasy from significant structure theory, Henry and I remained close. He invited me to join with him and Jost in editing a multi-volume treatise on physical chemistry. I was nervous about this and wondered if I was into something that was over my head. However, it worked out. The treatise was a success.

Despite the fact that, as time passed, Henry's work had become somewhat out of the main stream of theoretical chemistry, I really enjoyed my association with him. He was an exceptionally kind man. He helped me and my wife when we needed his support. He was modest and did not feel that he was any better than anyone else. He was genuinely interested in the personal and professional details of anyone he met and spoke with. He had a facility to make a person feel at ease in his presence.

He was also an engaging speaker. Perhaps he was at his best when he spoke about his research at Princeton into the effect of pressure on the behavior of tadpoles. The tadpoles would swim normally at atmospheric pressure but under pressure they behaved erratically and then behaved normally again 
when the pressure was reduced. Henry, when speaking about this experiment would act the part of the tadpoles and alternate between a normal state and an apparently intoxicated state while commenting on the effect of alcohol on the brain (he did not use or approve of alcohol as a beverage). The talk was hilarious and it was obvious that he was enjoying himself enormously.

\section{John Adair Barker (1925-95)}

John Barker appears in figure 2 a photograph that was given to me by his widow, Sally.

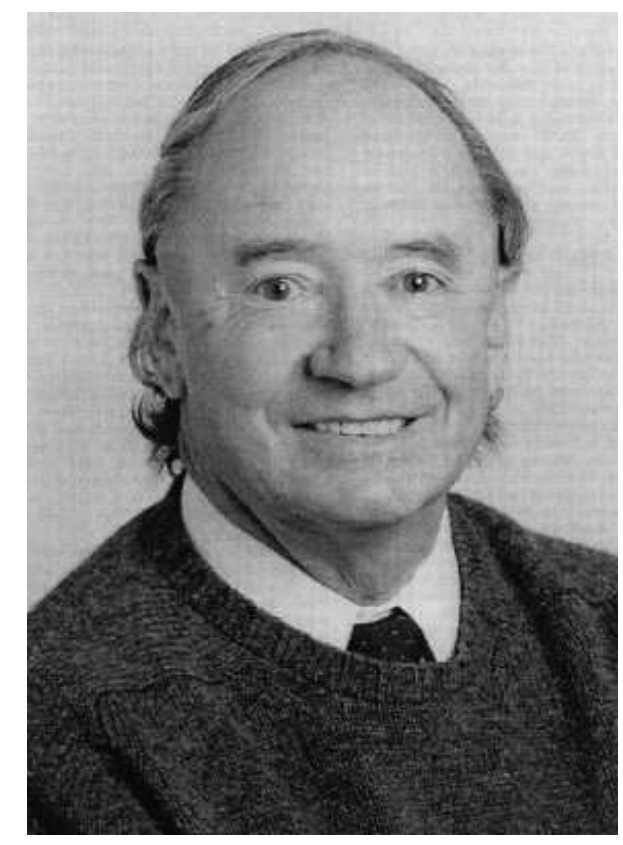

Figure 2. John Barker.

John was born in Corrigin, Western Australia, which is about 200 kilometers southeast of Perth. While he was young, he and his family moved to Red Cliffs in Victoria, Australia. Red Cliffs is near Mildura and is about 500 kilometers northwest of Melbourne. Similarly to Eyring, he grew up in a relatively isolated farming community. In fact, prior to jet aircrafts, Australia was perhaps even more isolated than Colonia Juarez. His father was a country medical doctor. John attended high school at a boarding school in Melbourne and then attended the University of Melbourne. At least once, presumably as an adventure, he chose to return home to Red Cliffs for school vacations by bicycle. His friends in Australia are still in awe of this feat that is indicative of John's vigor.

John graduated from the University of Melbourne in physics and mathematics. One of his professors was H.H. Corben, the author of an influential book on classical mechanics. Interestingly, I met Bert Corben and his wife by chance some years later in a restaurant in Mexico. John might have proceeded immediately to a doctoral degree. However, a family tragedy led to his spending a, not very happy, year teaching mathematics at a secondary school in England. During the long trip, by ship, back to Australia, he met Sally Johnston, whom he married soon after they had both arrived in Australia. They had two sons and a daughter. Since he now had a family to support, graduate studies were out of the question so he joined CSIR (now CSIRO), a federal government scientific organization, as a scientific officer in Melbourne. He was initially hired to provide theoretical support to the experimental work of Ian Brown. However, John was soon working independently and rose through the ranks of CSIRO to become a chief research officer. Several years after joining CSIRO, he presented a summary of his research as a thesis and was awarded a DSc degree by the University of Melbourne. 
Some of his early work at CSIRO involved the use of perturbation expansions. However, like Eyring and many other contemporaries, Barker felt that since the density of a liquid was similar to that of a solid, a lattice approach was the appropriate starting point for the development of a theory of the liquid state. His approach was more mathematical than the intuitive style of Eyring. Barker started with a lattice but attempted to introduce disorder and multiple occupancy in a systemmatic manner. Although perturbation expansions were employed in his lattice theory of liquids, Barker did not fully return to perturbation theory until I appeared on the scene about fifteen years later.

As I have mentioned, after obtaining my doctorate, I attempted to develop, with mixed success, the ideas of Eyring regarding holes in a lattice in a more systematic manner. Soon after graduation I published a paper that caught Barker's attention. He, and the Chief of the Physical Chemistry Division of CSIRO, Sefton Hamann, wrote to me and invited me to come to Melbourne and work with Barker. I replied positively and enthusiastically since I had admired the work of Hamann and Barker for some time but I was married and had two (soon three) small children and could not just take up and go. However, I arranged my affairs and as soon as I had accumulated enough 'credits' at the University of Waterloo for a sabbatical, and with the assistance of Alfred P. Sloan Foundation and Ian Potter Foundation fellowships, I went to Melbourne to work with John.

While at CSIRO in Melbourne, I was asked to give a series of lectures. By this time, I was drifting away from lattice theories. In my lectures, I discussed some recent work on perturbation theory about which I had just learned prior to coming to Melbourne. I discussed some recent papers of Rowlinson [4], Frisch et al. [5], and McQuarrie and Katz [6] who had attempted to start with a hard sphere fluid as an unperturbed or reference system and apply a perturbation expansion. The hard sphere fluid was an attractive starting point because there were accumulating data from simulations for the thermodynamics and structure of this fluid and, especially through the work of Wertheim [7, 8], convenient and accurate theoretical expressions for their thermodynamics and distribution functions. At the time the evidence was that these perturbation theories were interesting but applicable only to gas well above its critical temperature but not to a liquid because the temperature of a liquid was apparently too low for a perturbation series to converge. This led to Barker and me wondering whether this was due to the manner in which the repulsive part of intermolecular potential was treated and to the manner in which the intermolecular potential was divided into the potential of the unperturbed or reference fluid and the perturbation energy.

We decided that, to avoid these questions, we should consider first a system in which the repulsion was exactly hard. Before I went to Melbourne, Berni Alder had told me of his (as yet unpublished) molecular dynamics simulations for a hard sphere fluid with a square well attractive potential. Such a square well fluid seemed ideal for our needs. I wrote Berni and he generously agreed to provide his results in advance of publication. We found that the agreement of our expansion, to first order, with the, as yet unpublished, simulation results of Alder and the earlier simulations of Rotenberg [9] was promising and, with the inclusion of an intuitively attractive approximation for the second order term, the results of our version of perturbation theory gave excellent results for the entire liquid region [10].

Thus encouraged, Barker and I devised a scheme for treating the fact of the repulsive part of a more realistic intermolecular potential. The repulsive part of the intermolecular interaction of a realistic fluid, although very steep, is not infinitely steep. In our scheme, the perturbation expansion was formally the same as the earlier expansion based on a hard sphere reference fluid but now the diameter of the unperturbed hard sphere fluid was a function of the temperature.

We obtained [11] the following expression for the Helmholtz function of a fluid.

$$
\frac{A-A_{0}}{N k T}=\frac{1}{2} \rho \beta \int u_{1}(R) g_{0}(R) \mathrm{d} \mathbf{R}-\frac{1}{4} \rho \beta^{2} \int\left[u_{1}(R)\right]^{2} k T\left[\frac{\partial \rho g(R)}{\partial p}\right]_{0} \mathrm{~d} \mathbf{R}+\cdots,
$$

where $\rho=N / V$, the subscript 0 indicates that the quantity is that of the reference hard sphere fluid, and $\mathbf{R}$ is the distance between the centers of the molecules (or hard spheres). The function $g_{0}(R)$ is the radial distribution function of the reference fluid. The radial distribution function is strongly dependent on the density. However, the integral of $u_{1}(R) g_{0}(R)$ is nearly constant. The approximate second order term, given in equation (3), is very useful for many systems. We called this approximation the compressibility approximation. This approximation can be made even more simple by neglecting the density dependence of $g_{0}(R)$ in the the integral in the second order term. Praestgaard and Toxvaerd [12] extended the compressibility approximation to obtain an estimate for the higher order terms. 
It is worth noting that if the series is truncated at first order and if the density dependence of $g_{0}(R)$ in the integral is neglected, the first order term is a linear function of $\rho$, just as it is in the van der Waals and significant structure theories.

Perturbation theory has been very useful and important. It was, as stated by Rowlinson, a spectacular advance. It was the first successful theory for the liquid state. My stay in Melbourne was an exciting year. Interestingly, our theory uncovered an error [13] in some simulations of liquid mixtures. This is one of the very few instances that theory has corrected a simulation.

Additionally, perturbation theory clarified the problem with integral equation theories of liquids. The integral equation theories tended to yield poor results for the pressure. The reason for this is that the route from the radial distribution function (RDF) to the pressure is very sensitive to errors in the RDF. By contrast, perturbation theory relies on the free energy, which is not so sensitive. In fact, we [14] showed that if an integral equation approach is used to calculate the energy and if the free energy is then obtained by numerical integration and then the pressure is obtained by numerical differentiation, excellent results are obtained. Of course, all this numerical integration and differentiation is cumbersome. Much of the reason for the success of the mean spherical approximation is that, for some systems, the free energy and pressure can be obtained from the energy without numerical integration and differentiation.

Subsequently, Weeks et al. [15] and my former graduate student, Bill Smith, together with Keith Gubbins and their colleagues, [16] developed an alternative version of perturbation theory that is based on a different division of the potential into reference and perturbation terms. This approach leads to a more rapid convergence. However, with the compressibility approximation for the second order term, equation (3) is equally accurate and as user friendly as this approach. The two approaches are equivalent for fluids with a hard core.

The last part of Barker's career was devoted to obtaining accurate results for interactions between molecules and surfaces. His expression for the interaction potential between the inert gas molecules was highly accurate. He found that the evidence about the pair interactions between argon molecules that was obtained from viscosity and scattering experiments was inconsistent. He made a bold step of abandoning the viscosity results and proposed an useful expression for the argon pair potential. It is bold for a theoretician to use theory to reject experimental results. New viscosity experiments supported his view. Barker's last project concerned the interaction of gas molecules with surfaces. His passing prevented the completion of this work.

No matter how well you know someone, you never know everything. After John passed away, I learned that he wrote poetry.

\section{Concluding remarks}

It is interesting for me to note that I am a coauthor of Eyring's last scientific work, a book, and that Barker's last publication was a generous appraisal of me and my work. I have also mentioned Sefton Hamann, another distinguished scientist. He helped facilitate my year in Melbourne. I never worked closely with him but did like him. Years later, and after both Eyring and Barker had passed away, I had an occasion to spend a couple of weeks at the University of Melbourne and during my stay had lunch with Sefton and his wife, Elizabeth. Sefton and I discussed how the "established" theories of liquid mixtures failed to account for some of the properties of liquid mixtures that interested him. Subsequently, Sefton and I showed in a simple way how perturbation theory provided the insight that he was seeking. After Sefton's passing, I was told that this was Sefton's last paper. I seem to specialize in last papers. As an added evidence of this, I mention that I am a coauthor of the last papers of Peter Leonard, one of my students. My colleagues should be aware that any paper they publish with me may be their last. I debated about whether I should include Sefton more fully in this reminiscense but decided not to do so. I admired Sefton but did not work closely with him as I did with Henry and John.

There are some echos of Eyring in my life. We are members of the same, small but growing, Church. We both lived in Mexico for a period. He and I worked in a copper mine while we were students. He worked and my parents (but not me) lived in Dahlem in west Berlin.

A comparison of Eyring and Barker is difficult and not very meaningful. However, an attempt is required. Eyring's work was uneven. His later work was not as important as his early work. Barker's work 
was more even but not as influential as Eyring's early work. In any case, both were outstanding scientists and splendid persons and I have great affection for both of them.

The families of Henry Eyring and John Barker have told me that both Henry Eyring and John Barker regarded me as an honorary family member. I am grateful for this. In any case, they both were admirable men and scientists. I am better as a scientist and a person for having known and worked with them.

\title{
References
}

1. Eyring H., Polanyi M., Z. Phys. Chem. B, 1931, 12, 279 (in German) [Z. Phys. Chem., 2013, 227, 1221; doi 10.1524/zpch.2013.9023].

2. Eyring H., J. Chem. Phys., 1935, 3, 107; doi 10.1063/1.1749604

3. Eyring H., Ree T., Hirai N., Proc. Natl. Acad. Sci. USA, 1958, 44, 683; doi 10.1073/pnas.44.7.683

4. Rowlinson J.S., Mol. Phys., 1964, 8, 107; doi 10.1080/00268976400100141.

5. Frisch H.L., Katz J.L., Praestgaard E., Lebowitz J.L., J. Phys. Chem., 1966, 70, 2016; doi 10.1021/j100878a051

6. McQuarrie D.A., Katz J.L., J. Chem. Phys., 1966, 44, 2393; doi 10.1063/1.1727054

7. Wertheim M.S., Phys. Rev. Lett., 1963, 10, 321; doi 10.1103/PhysRevLett.10.321

8. Wertheim M.S., J. Math. Phys., 1964, 5, 643; doi 10.1063/1.1704158

9. Rotenberg A., J. Chem. Phys., 1965, 43, 1198; doi 10.1063/1.1696904.

10. Barker J.A., Henderson D., J. Chem. Phys., 1967, 47, 2856; doi $10.1063 / 1.1712308$

11. Barker J.A., Henderson D., J. Chem. Phys., 1967, 47, 4714; doi 10.1063/1.1701689

12. Toxvaerd S., Praestgaard E., J. Chem. Phys., 1970, 53, 2389; doi 10.1063/1.1674336.

13. Leonard P.J., Henderson D., Barker J.A., Trans. Faraday Soc., 1970, 66, 2439; doi $10.1039 /$ tf9706602439

14. Grundke E.W., Henderson D., Murphy R.D., Can. J. Phys., 1971, 49, 1593; doi 0.1139/p71-186

15. Weeks J.D., Chandler D., Andersen H.C., J. Chem. Phys., 1971, 54, 5237; doi 10.1063/1.1674820

16. Gubbins K.E., Smith W.R., Tham M.K., Tiepel E.W., Mol. Phys., 1971, 22, 1089; doi 10.1080/00268977100103401

\section{Вони відійшли, але їх не забули}

\author{
Д. Гендерсон \\ Відділ хімії та біохімії, Університет Брігема Янга, Прово, штат Юта 84602-5700, США
}

У цих спогадах я обговорюю той вплив, який Генрі Ейринг і Джон Баркер мали на моє життя та роботу. Хоча інші, особливо моя сім'я, мали навіть більший особистий вплив на мою особистість. Безперечно й інші, які прийшли ще раніше, ніж Ейринг і Баркер, особливо Больцман і Ван дер Ваальс, а пізніше Онсагер та сучасник Ейринга Кірквуд мали вплив на мене, але лише опосередковано, оскільки я ніколи не зустрічався з ними. Однак Ейринг та Баркер не єдині вчені, які надихали мене. Багато з тих, хто впливали на мене вже подали свої статті у цей спеціальний випуск або ж працювали зі мною. Я виокремлюю саме Ейринга і Баркера тому, що зустрівся з ними на початку моєї кар'єри і тому, що вони вже відійшли і зараз присутні лише своїм духом. Вони відійшли, але не повинні бути забутими. Я користаюсь цією нагодою, щоб нагадати читачам про цих двох визначних науковців та чудових людей і пропоную вам ці спогади, як подяку їм.

Ключові слова: хімічна кінетика, теорія рідин, теорія збурень 


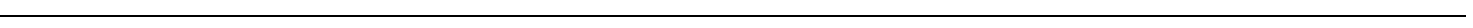

